\title{
WELFARE REFORM: CHULD WELFARE OR THE RHETORIC OF RESPONSIBILITY?
}

\author{
AlEXIA PAPPAS \\ INTRODUCTION
}

The Uinited States has reached one of those rare junctures in its pohtical history when consensus exists between leaders in both political parties about radical changes in federal social pohicy. The Repubhican Congress has targeted welfare reform as one of its top priorities in the "Contract with America," which Republicans proinote as a "detailed agenda for national renewal." Similarly, President Clinton lias pledged to "end welfare as we know it" through his "Work and Responsibility Act of 1994."

Despite promises to bring about change, both the Clinton reforn bill and the Republican Contract are precisely what they purport not to be: a reprise of failed welfare initiatives from the past that focus bluntly on controlling parental behavior. Past initiatives have been structured around social engineering efforts to classify the poor as "deserving" or "undeserving." Status in a so-

1. House Republicans signed the "Contract witt America" during their 1994 campaigns. See Helen Dewar, Historic Session Leaves Minor Legislative Legacy; Historic Congress's Busy Session Results in Relatively Few Laws, WASH. POST, Jan. 2, 1996, at A1, A4. The Contract includes ten bills; its signees pledged to bring these bills to the House floor within the first 100 days of the 104th Congress. HOUSE REPUBLICANS, CONTRACT WITH AMERICA 8-9 (Ed Gillespie \& Bob Schellhas eds., 1994). Included in the list is the Personal Responsibility Act of 1995, H.R. 4, 104th Cong., 1st Sess. (1995), which is the Repnblicans" punitive solution to "welfare dependency." See discussion infra part III.B.

2. See CONTRACT With AMERICA, supra note 1, at 7.

3. Jason DeParle, Froin Pledge to Plan: The Campaign to End Welfare, N.Y. TMMES, July 15,1994 , at A1.

4. H.R. 4605, 103d Cong., $2 d$ Sess. (1994).

5. See, e.g., Joel F. HANDLER \& YeHESkel HASENFELd, THE MORAl CONSTRUCTION OF POVERTY: WELFARE REFORM IN AMERICA 37 (1991) ("[T]he evolution of welfare policy is, in large part, the process of creating and revising the moral classifications of the poor."); MichaEl B. KATZ, THE UNDESERVING POOR 67 (1989) (explaining how even critics of welfare distinguished between those who "[fell] into poverty through indolence and inteunperance" and those who were "worthy poor"); Martha Fineman, Images of Mothers in Poverty Discourses, 1991 DUKE L.J. 274, 280-81, 282 ("This classification is 
cial group determined these classifications: unemployed men and single women were responsible for their own situations and therefore undeserving, whereas widows with children were blameless victims who had conformed to societal norms by marrying the fathers of their children and therefore were deserving of assistance. ${ }^{6}$ Both the Clinton reform bill and the Republican Contract repeat this classification error by focusing on parental behavior at the expense of a second, more positive guiding force. That force is child welfare, and it has competed over time with policies intended to control the behavior of adults.

Policies focusing on child welfare rather than on parental incentives have driven legislative ${ }^{7}$ and judicial ${ }^{8}$ recognition of at least two significant national values: family preservation as a social good and the unfairness of controlling parental behavior by punishing children. The Clinton/Republican direction of welfare reform, by focusing on parental beliavior control, threatens to nullify the vital progress that child-centered policy has made toward protecting the well-being of poor children. Current Democratic and Republican welfare reform proposals cloak their indirect assaults on poor children" by focusing on their parents' morality and "responsibility." In their clamor to reclaim the so-called moral high ground, both parties are guilty of liypocrisy. Their emphasis on

often based on the public's perception of whether the impoverished individual is poor because of her personal choices ... or as a result of forces beyond her control.").

6. KATZ, supra note 5, at 67 ("Upriglt widows with clrildren and old women remained the quintessential worthy poor.").

7. See infra part I.

8. See infra part $I I$.

9. At last count 14.6 million American children, or $21.9 \%$ of the child population, were living in poverty. THE CHILdREN's DEFENSE Fund, THE STATE of AMER1CA's CHILDREN YEARBOOK 2 (1994). This estimate is computed according to the Department of Health and Human Services' (HHS) poverty line, which was $\$ 12,320$ for a three-person family in 1994. Annual Update of the HHS Poverty Guidelines, 59 Fed. Reg. 6277, 6277 (1994). For arguments that the poverty line is inaccurately low, see Kathryn Edin \& Christopher Jencks, Reforming Welfare, in RETHINKING SOCIAL POLICY: RACE, POVERTY, AND THE UNDERCLASS 204, 209 (Christopher Jencks ed., 1992).

10. See infra Part III. As an alternative to responsibility rletoric, the staggering number of poor children may be explained in part by economic and demographic changes in the country since the time welfare was introduced as a national prograin. See JAMES T. PATTERSON, AMERICA's StrugGle AGainst POVERTY, at viii, 215, 218-23 (2d ed. 1986). These changes in the economic landscape include women's increased participation in the work force, DAVID T. EllwOOD, POOR SUPPORT 47-49 (1988), and the restructuring of the economy and corresponding labor market problems, Laurence E. Lynn, Jr., Ending Welfare Reform as We Know It, THE AMERICAN PROSPECT, Fall 1993, at 83, 85-87. 
"responsibility" is fundamentally irresponsible policy because it ignores a core societal value: protecting our children. ${ }^{11}$ This core value has been supported by policy developments and reinforced by judicial decisions holding unconstitutional state public assistance prograins that punish children to influence parental behavior. The current debate ignores this legal and political history. Current proposals also would fail to achieve their purpose of affecting the behavior of welfare recipients since they do not address the realities of being poor. ${ }^{12}$

Part I of this Note addresses the history of the welfare state and welfare reform in the United States. This history has been animated by the often conipeting goals of ensuring the welfare of children, on the one hand, and adult behavior modification, or socializing adults to engage in "responsible" behavior, on the other. Part II traces the gradual establishment of child-centered welfare pohicy in caselaw and denionstrates, through the example of "child exclusion" laws, ${ }^{13}$ that welfare reformers" current pohcies liave a misguided legal basis and may in fact be unconstitutional. Part III discusses President Clinton's welfare reform package, which includes both a "full family sanction"14 and biberalized "child exclusion" laws. This Part also examines the Republican Contract With America, which outlines an even more punitive welfare reform initiative. Part III critiques these current welfare reform proposals and concludes that they are founded on niyth and misconception. President Clinton and the Republican welfare reformers head in the wrong direction by focusing on controlling parental conduct instead of child welfare. Although the routes that President Clinton and the Republicans want to take may be pohitically expedient, they threaten, in the name of "responsibility," to eviscerate society's noral commitınent to provide for children.

11. To put it another way, Professor Minow aptly asks, "[A]re single mothers on welfare properly to be viewed as dependent people who should become economically self-reliant, or as people upon whom children depend, and people upon whom society depends to raise those children successfully?" Martha Minow, The Welfare of Single Mothers and Their Children, 26 CONN. L. REv. 817, 822 (1994).

12. See infra text accompanying notes 122-30.

13. "Child exclusion" laws deny additional benefits to a family when a child was conceived after the family is receiving public assistance. The administration's proposal liberalizes current law in that it does not require states to obtain a waiver from HHS to implement "child exclusion" laws. See discussion infra part III.A.

14. A "full family sanction" throws an entire family off welfare when a parent fails to comply with behavioral requirements. See infra text accompanying notes 141-42. 
This moral commitment has evolved through welfare policies, legislation, and judicial holdings regarding children's rights under welfare law. ${ }^{15}$

\section{The Historical Development of Welfare as a Moral COMMITMENT TO CHILDREN AND FAMILIES}

Debates about welfare reform have often drawn distmctions between the "deserving" and the "undeserving" poor. ${ }^{16}$ Throughout the political history of welfare, children traditionally have been deemed the most innocent poor, and therefore the most "deserving" of public assistance. Thus, the major federal transfer programs for the poor focus on providing aid to children, either through monetary assistance such as Aid to Families with Dependent Children (AFDC), or through in-kind benefits, such as Food Stamps and housing subsidies. Although welfare policy first aimed to renove poor children froin their families, policymakers and advocates for the poor eventually came to a consensus that welfare should aim to keep children with their parents. This lesson was learned early in the twentieth century. ${ }^{17}$ Thus policymakers have constructed a welfare system that provides parents with aid, whether or not they are morally "deserving" by the standards of the rest of society, in order to reach their needy children.

\section{A. An Evolving Recognition That Children Should Remain with Their Families: The Origins of Welfare for Children}

Early nineteenth-century programs for the poor featured work requirements, local administration and stigmatization. ${ }^{18}$ First, assistance was conditioned on employment or participation in work programs. ${ }^{19}$ Second, state welfare statutes gave complete discretion to local administrators, prescribing "neither ehigibility nor budget." ${ }^{20}$ Third, poorhouses operated as the primary relief mechanism at the time, depriving the destitute of liberty and segregat-

15. See infra parts I \& II.

16. See supra note 5 .

17. See infra notes $30-35$ and accompanying text.

18. Joel F. Handler, The Transformation of Aid to Families with Dependent Children: The Family Support Act in Historical Context, 16 N.Y.U. Rev. L. \& SOC. CHANGE 457, 467-70 (1987-88).

19. Id. at 469 .

20. Id. at 470 . 
ing them from the rest of society. ${ }^{21}$ Poverty policy slowly recognized the failures of these features, at least as they related to the welfare of the children in poor families. The "core values of the AFDC program" subsequently emerged: children are better off in their own homes than in public custody; people receiving welfare should be treated equitably; and "children should not be penalized for the behavior of their parents."22

Nimeteenth-century policymakers classified the poor "in terms of moral blameworthiness." ${ }^{23}$ Such categorizing can be attributed in part to the post-Civil War environment, in which mdigent war veterans were classified separately from other groups of the poor. ${ }^{24}$ Classification coincided with the institutional movement, which introduced orphanages to shelter children who did not have hiving parents or whose parents were too destitute to provide for them. ${ }^{25}$

By the turn of the twentieth century, social programs for children had fully bifurcated along limes of parental status. Orphaned and disabled children were the "deserving" poor, while children in poor families were labeled as "undeserving." makers believed that providing poor children with too much public assistance would interfere with their parents' work incentives. ${ }^{27}$ The nineteenth-century policy empliasis on who "deserved" the state's assistance and who did not contrasts sharply with the goal of family preservation that emerged during the Progressive Era.

The emergence of the Child Saving Movement durmg the middle of the nineteenth century initially contributed to welfare policies that encouraged breaking up poor families. Primarily an elite-to-middle class women's movement, the Child Savers originally worked to remove poor children from their "bad" home envi-

21. Id. at 468 .

22. Susan Bennett \& Kathleen A. Sullivan, Disentitling the Poor: Waivers and Welfare "Reform," 26 U. MICH. J.L. REF. 741, 743 n.16 (1993). These "core values" also hold that reductions in benefits should be accompanied by fair process, and that administration of welfare should be consistent across states and regious. Id.

23. Handler, supra note 18 , at 470 .

24. See THEdA SKopCol, Protecting Soldiers AND MOtHERS 102-03 (1992).

25. See generally SUSAN TIFFIN, IN WhOSE BEST INTEREST? CHILD WELFARE REFORM IN THE PROGRESSIVE ERA 61-87 (1982) (describing institutional care).

26. See Handler, supra note 18 , at $471-72$.

27. See Joel F. Handler, Two Years and You're Out, 26 CONN. L. REV. 857, 857 (1994) ("The overriding fear was that giving aid indiscriminately would destroy the incentive to work ...."). 
ronments. ${ }^{28}$ Eventually, the Child Savers realized the cruel reahties of institutions and the value of home life to a child's longterm well-being and took up the cause of family preservation. ${ }^{29}$

This tension persists in the current welfare reform debate. The predecessors to AFDC, currently the program inost people are referring to when they discuss welfare, were the states' "Mothers' Pension Programs,"30 first created in Illinois in 1911. Social reformers promoted Mothers' Pensions because they had come to beheve in family preservation and saw the pension prograins as a means to enable destitute children to remain at hoine, rather than being placed in foster care. ${ }^{31}$ By 1935 , every state except Georgia and South Carolina had a pension program, or "mother's aid law."32 Although the programs had moralistic overtones and condoned interference in the privacy of recipients' hives, ${ }^{33}$ they represent an early recognition of the benefits and importance of parental child-rearing.

This recognition was demonstrated best by the 1909 White House Conference on Dependent Children, where recommendations were made to establish a Federal Children's Bureau and to make "greater provision ... for the assistance of needy children in their own homes." ${ }^{34}$ Eleven years after this conference, the Committee on Dependency and Neglect reported that "soine

\footnotetext{
28. See Handler, supra note 18 , at 471.

29. Handler, supra note 27; see also TIFFIN, supra note 25, at 110-11:

Whereas nineteenth-century child-savers were mainly concerned with removing children from dangerous influences, their successors in the Progressive era believed that dependency and neglect might be prevented. . . . By preserving and reconstructing the family unit, the child-savers hoped to reduce the numbers of dependent and neglected children in institutions and foster hoines.
}

30. S. REP. No. 628, 74th Cong., 1st Sess. 17-19 (1935) (stating that AFDC and the Social Security Act were built on the earher "mothers' pensions" programs).

31. WINIFRED BELL, AID TO DEPENDENT ChILDREN 4 (1965) ("No child should be deprived of his family by reason of poverty alone.") (citation omitted); GRACE ABBOTT, From Relief to Social Security, The Development of the New PUBlic WelFARE SERVICES AND THEIR ADMINISTRATION 263 (1966) (describing New Jersey's legislation as an act "to promote home life for dependent children."). For a history of Mother's Pension Programs, see BELL, supra, at 3-19; see also LINDA GORDON, PITIED BUT NOT ENITILED: SINGLE MOTHERS AND THE HISTORY OF WELFARE 1890-1935, at 37-64 (1994); MOLLY LADD-TAYLOR, MOTHER-WORK 135-66 (1994); THEDA SKOPCOL, PROTECTING SOLDIERS AND MOTHERS: THE POLITICAL ORIGINS OF SOCIAL POLICY IN THE UNITED STATES 424-79 (1992).

32. ABBOTT, supra note 31 , at 263.

33. GORDON, supra note 31 , at $45-46$.

34. White House Conference on ChILd HeAlth and PRotection, PrelimiNARY COMMITTEE REPORTS 500 (1930). 
220,000 needy children are hiving im their own homes and cared for by their own mothers through the operation of mothers' aid laws." ${ }^{35}$ Although these state programs continued to scrutinize parents' noral worthiness, keeping poor families intact had emerged as a primary objective of national social policy.

The Children's Bureau's primary success was enactment of the first federal welfare program, the Sheppard-Towner Act of 1921. ${ }^{36}$ This Act expressed a national recognition that pregnancy is a time of special need; the legislation provided assistance without means-testing (aid not based on recipients' income) for maternal and child hygiene programs. ${ }^{37}$ The current welfare reform proposals contravene this social value, treating pregnancy as a time of reprisal and abandonment by society, rather than a time of special need. ${ }^{38}$

B. Family Preservation Despite "Unsuitable Homes" or Parental Misbehavior: The Social Security Act of 1935 and Evolving AFDC Standards

AFDC $^{39}$ emerged from the Social Security Act of $1935^{40}$ The AFDC program, an exainple of "cooperative federalism,"41 is a state-implemented program that receives federal matching funds, subject to approval by the U.S. Department of Health and Human Services (HHS) ${ }^{42}$ Froin its inception, the AFDC program, like nineteenth-century reform movements, exhibited the tension between policy focused on adult behavior and policy focused on the well-bemg of children. AFDC eligibility imitially was state-determined. A state could "impose such . . . ehgibility requirements-as to means, moral character, etc.-as it [saw] fit." ${ }^{\prime 3}$ States set the

35. Id. at 501.

36. See LADD-TAYLOR, supra note 31, at 167-96.

37. See, e.g., GoRDON, supra note 31, at 94-95.

38. See infra part III; see also infra part II.B. (discussing "child exclusion laws" which purport to deter pregnancies).

39. Social Security Act, ch. 531, §§ 401-06, 49 Stat. 620, 627-29 (1935) (codified as aneuded at 42 U.S.C. $\$ \S 601-17$ (1988 \& Supp. V 1993)).

40. Social Security Act, ch. 531, 49 Stat. 620 (1935) (codified as amended at 42 U.S.C. $\$ \S 301-1397 f$ (1988 \& Supp. V 1993)).

41. King v. Smith, 392 U.S. 309, 316 (1968).

42. 42 U.S.C. $\$ \S 601-02$ (1988 \& Supp. V 1993).

43. S. REP. No. 628, 74th Cong., 1st Sess. 36 (1935). Not surprisingly, state discretion led to racial discrimination in the administration of AFDC, as "southern states [were able to] perpetuate the same patterns of racial exclusion as they had [before enactment of a 
level of benefits as well as the standard of need, creating wide variations across the country. In 1939, for example, participating states' average inonthly payments ranged from $\$ 8.10$ per family in Arkansas to $\$ 61.07$ per family in Massachusetts. ${ }^{44}$

Congress reacted to soine of the interstate inconsistencies with legislation. Whereas the 1935 Act deinanded only that states provide funds "as far as practicable under the conditions in such states," ${ }^{45}$ resulting in exclusion of more than two-thirds of eligible dependent children in $1940,{ }^{46}$ Congress eventually required states to pay assistance "to all eligible individuals." 47 This provision currently prohibits the states from narrowing the categorical eligibility requirements that the Social Security Act established. ${ }^{48}$ Congress also reacted to the most overt discrimination against welfare families with legislative clianges designed to minimize abuse of the benefit application process. ${ }^{49} \mathrm{~A}$ national administrative standard was conclusively articulated by the Flemming Rule of $1961 .^{50}$ This Rule, based on the Secretary of Health, Education, and Welfare's conclusions regarding justice and children's needs, forbade states froin denying benefits to children based on moral judgments about their family environments. ${ }^{51}$ The Flemming Rule was articulated in a letter which provides the following direction to state agencies:

federal program]." Bennett \& Sullivan, supra note 22, at 743. For a discussion of recent "behavior modification" proposals in state welfare programs, see Lucy A. Williams, The Ideology of Division: Behavior Modification Welfare Reform Proposals, 102 YALE L.J. 719 (1992).

44. PATTERSON, supra note 10 , at 69.

45. Id. at 68 (citation onnitted).

46. Id.

47. 42 U.S.C. $\$ 602(a)(10)(A)(1988)$.

48. King v. Snith, 392 U.S. 309, 333 (1968).

49. See, e.g., Social Security Act Amendments of 1950, ch. 809, tit. III, $\S \S 321(\mathrm{a})$, 402(a), 64 Stat. 477, 549 (codified as amended at 42 U.S.C. $\S 602$ (a)(4) (1988)).

50. This Rule is named after the Secretary of Health, Education, and Welfare who authored it, Arthur S. Flemming. Flemming stated:

I have concluded that when a needy child who otherwise fits withm the Aid to Dependent Children program of the State is denied the funds that are admittedly needed to provide the basic essentials of life itself, because of the behavior of his parent or other relative, the State plan inposes a condition that bears no just relatiouship to the Aid to Dependent Children program. I therefore believe that this Department should imform the State agencies administering Aid to Dependent Children plans that eligibility conditions with the effect described above are not conpatible with entitleunent for continued Federal grants.

Letter from the Director of the Bureau of Public Assistance to State Agencies. (Jan. 17, 1961) (on file with author).

51. Id. 
A state plan for aid to dependent children may not impose an eligibility condition that would deny assistance witl respect to a needy child on the basis that the home conditions in which the cliild lives are unsuitable $\ldots . .52$

The Flemming Rule represented a crucial advancement of childcentered welfare policy over policy focused on society's notions of moral or "responsible" parental behavior.

In addition to barring denial of benefits based on moral judgnients about parental beliavior, policy in the 1960s expanded AFDC to imclude support for children of unmarried parents and deserted parents. "Absent father" rules, which previously had denied AFDC benefits to families if the mother "coliabited" with an able-bodied nian, were judicially invalidated, ${ }^{53}$ and federal regulations were issued to decrease local control. ${ }^{54}$ Overall, child-focused welfare policy was gaining the upper hand, and the goal of controlling parental behavior was being abandoned largely as ineffective policy.

AFDC policies in the 1980s and 1990s reopened the conflict in welfare policy between child welfare and attenipts to control parental beliavior. Welfare controversy during the Reagan, Bush and Clinton administrations lias focused on the proliferation of AFDC "waivers." These waivers permit states to engage in AFDC "expermients" or "projects" if they obtain permission fron HHS to diverge from the basic requirement to provide assistance "to all eligible imdividuals" within the state. ${ }^{56}$ Waivers are granted when they will be "likely to assist in promoting the objectives" of the Social Security Act, or when they conform to the Congressional

52. Id.

53. King v. Smith, 392 U.S. 309, 333-34 (1968).

54. Handler, supra note 18 , at 481 . These initiatives increased the number of nonwhite welfare recipients. Many scholars argue that societal attitudes toward this "new clientele"-black, poor, feinale-headed households - are the inpetus behind current efforts at punitive policy change. See generally THOMAS B. EDSALL \& MARY D. EDSALL, CHAIN REACTION (1991) (arguing that the shift in political power to the right over the last generation has intensified the view among many whites that the responsibility for the disadvantaged lies with those afflicted); Handler, supra, at 466-67, 483 (arguing that the welfare reform consensus is based, in part, on the notion that welfare encourages dependency, which is then passed on to children of parents on welfare).

55. See, e.g., Bennett \& Sullivan, supra note 22; Lucy A. Williams, The Abuse of Section 1115 Waivers: Welfare Reform in Search of a Standard, 12 YALE L. \& POL'Y REV. 8 (1994).

56. 42 U.S.C. § 1315 (1994). 
purpose of the Act. ${ }^{57}$ Waivers have been used by the states to experiment in areas such as Learnfare, ${ }^{58}$ where benefits are reduced when parents fail to force their children to attend school. States have also used waivers to impose family caps, ${ }^{59}$ which deny benefits for additional children born to AFDC fainilies whose incomes have reached a predetermined income "cap," or limit. These "experiments" foreshadowed the Clinton and House Repubhican plans' reversion to morahistic behavior control as a pohicy goal that trumps conflicting child welfare concerns.

The above discussion demonstrates that AFDC standards have long reflected the tensions between pohicies aimed at controlling parental behavior and policies intended to promote child welfare. Welfare reform debate in the 1990s also reflects a tension between AFDC's essential purpose and the reality of the American family. The imderlying and underriable purpose of AFDC when it was created in 1935 was to provide financial support to needy children. ${ }^{60}$ Legislators in the 1930s believed that children were "the nost tragic victims of the depression"61 and that "[t]le heart of any program for social security inust be the child." program that grew out of this belief was based on a family "breadwinner" model: Assistance was intended for clildren whose natural "breadwinner" parent, the father, was absent. ${ }^{63}$ For this reason, AFDC lias been described as representing a "national commitinent to the idea that a inotlier's place is in the hoine."64 The presence of mothers in the work force, due to either necessity or choice, renders this model obsolete. ${ }^{65}$ Perhaps this explains

57. California Welfare Rights Organization v. Richardson, 348 F. Supp. 491, 497 (N.D. Cal. 1972).

58. See Handler, supra note 27 , at 860 ; Williams, supra note 43 , at $726-36$.

59. See Handler, supra note 27 , at 860 ; Williams, supra note 43 , at $736-41$.

60. AFDC has been described as "an afterthought, meant to aid widows with children, such as the wives of uninsured workers killed in mine disasters." Richard P. Nathan, The Welfare Long Shot, WASH. POST, Sept. 18, 1994, at C2. In 1935, 88\% of the families that received welfare were families in which the father had died. VEE BURKE, CONGRessional Research SERVICE IsSUe Brief, Time Limited Proposals 9 (1994).

61. H.R. REP. No. 615, 74th Cong., 1st Sess. 9 (1935).

62. S. REP. No. 628, 74th Cong., 1st Sess. 16 (1935).

63. See H.R. Doc. No. 81, 74th Cong., 1st Sess. 4-5, 29-30 (1935); see also 79 CONG. REC. 5468, 5476, 5786, 5861 (1935).

64. Judith $M$. Gueron, Welfare and Poverty: The Elements of Reform, 11 YALE L. \& POL'y REV. 113, 113 (1993) (quoting GILBERT Y. STEINER, THE STATE OF WELFARE 54 (1971)); see also Jared Bernstein, Rethinking Welfare Reform, DISSENT, Summer 1993, at 277 ("The initial goal was to keep both mother and child out of the work force.").

65. See, e.g., Minow, supra note 11, at 826 . Mimow argues that working women who 
why welfare is being assaulted with such rigor today. ${ }^{66}$ Because nany American families no longer fit a "breadwinner/hoinemaker" nodel, the underlying rationale behind AFDC is no longer apphcable. It seems unfair to many Americans to give a subset of the population financial support in exchange for caregiving, when inany mothers work outside the home and raise children. These fairness concerns, however, obscure the reahty of the program: AFDC has always been intended to provide assistance to needy children, particularly children with a inissing parent. ${ }^{67}$ This fundainental purpose reınains a viable and appropriate goal when milhons of American children hive in poverty. ${ }^{68}$

\section{Federal Work Programs under AFDC: WIN and JOBS}

The impulse to jom work requirements with the provision of public assistance has influenced welfare policynakers since the early nineteenth century. ${ }^{69}$ AFDC has been no exception to the general rule that welfare and work frequently are linked together. While work programs may make intuitive sense as sound welfare policy because they promote job skills and work habits, work requirements have failed to achieve their intended goals of proinoting family self-sufficiency and discouraging welfare "dependency." The failure has been due largely to inadequate funding. Job training is expensive and past work programs, although implemented during a time of relative generosity toward public assistance programs, were consistently underfunded. ${ }^{70}$

The 1960s saw implementation of federal work requirements for AFDC families. The first program, the Work Incentive Pro-

$$
\therefore
$$

are not on welfare differ from women adhering to welfare work requirements in a crucial way: Only women receiving welfare benefits are forced by the government to work. In addition, she points out that many working mothers only work part-time or part of the year. Id. at 826-27.

66. A recent poll found that Americans rate welfare reform as a higher priority than health care reform, although the total budget for AFDC is only $\$ 23$ billion, while the total budget for health care is $\$ 900$ billion. Handler, supra note 27 , at 865 .

67. H.R. REP. No. 615, 74th Cong., 1st Sess., 9-10 (1935) (declaring children to be "the most tragic victims of the depression"); S. REP. No. 628, 74th Cong. 1st Sess. 16-17 (1935) (stating that the "heart of any program for social security must be the child"); King v. Smith, 392 U.S. 309, 327-30 (1968) (holding that the economic security of needy children is the paramount interest).

68. See supra notes 9-10.

69. Handler, supra note 27 , at 858 .

70. See infra text accompanying notes 79-100. 
gram (WIN), ${ }^{71}$ was based on "[t]he prevailing view in Congress ... that welfare undermined family stability and work incentives."72 Men had to participate in WIN, but participation for woinen was voluntary. ${ }^{73}$ The prograin categorized participants as "immediately einployable," in need of training, or unemployable. $^{74}$ The unemployable group was given "special works projects," which have come to be known as "workfare," or made-up work, in exchange for welfare benefits. ${ }^{75}$

WIN has not succeeded. First, WIN placements arguably are not the result of WIN, but would have occurred in the absence of the program. ${ }^{76}$ Second, although participants in WIN received lower grants due to their work income, these savings to the government fell short of their associated costs. ${ }^{77}$ WIN therefore deinonstrates that work programs linked to welfare are more costly than direct financial assistance. ${ }^{78}$ Third, those people who found einployment through WIN often remain dependent on welfare because of madequate wages. ${ }^{79}$ WIN neither ended "welfare dependency" nor helped recipients to achieve self-sufficiency. For these reasons, "[g]overnment studies of WIN uniformly conclude that it has not achieved its objective of forcing the poor to become economically independent." ${ }^{80}$

Aware of WIN's failings, Congress attempted unsuccessfully to make WIN more effective. The Talınadge Amendments of 1971, or WIN $\mathrm{II}^{81}$ toughened work requirements and emphasized placement in entry-level jobs over training. WIN II also failed, again due to the costs of work programs and a lack of resources. ${ }^{82}$

71. 42 U.S.C. $\S 602(a)(19)$ (1988).

72. Handler, supra note 18 , at 489.

73. Id. at 490.

74. Id.

75. Id. at $489-91$.

76. Id. at 490 .

77. Id.

78. The average grant to an AFDC family with two children is $\$ 4,400$ per year, whereas enrollment in a work progran costs abont $\$ 11,400$; work programs for the entire welfare population would therefore cost approximately $\$ 15$ billion per year. Jason DeParle, Better Work Than Welfare, But What if There's Neither? N.Y. TIMES, Dec. 18, 1994, at 44.

79. See Sylvia A. Law, Women, Work, Welfare \& the Preservation of the Patriarchy, 131 U. PA. L. REV. 1249, 1273 (1983).

80. Id. at $1273-74$.

81. 42 U.S.C. $\S 633$ (1994).

82. Handler, supra note 18 , at 491. 
The Family Support Act of 1988 (FSA) ${ }^{83}$ establislied the only other federal work program affiliated with AFDC. The FSA, which had bipartisan support, includes among other things the Job Opportunity and Basic Skills Program (JOBS) ${ }^{84}$ By mandating that all states implement work programs, ${ }^{85}$ JOBS' creators intended to change welfare from an entitlement program to a workbased system. ${ }^{86}$ Specifically, the FSA requires all mothers with children over six years of age to work. ${ }^{87}$ States can lower that age with a federal waiver. ${ }^{88}$

Like WIN, JOBS has been unsuccessful. Despite the general willingness of Congress in the 1980s to spend beyond its ineans, the JOBS program has been "starved for the funding necessary to put the reforms into practice." 89 Moreover, although JOBS imposes an obligation on some welfare mothers to work, it has been remarkably ineffective in reducing poverty. ${ }^{90}$ The first component of JOBS, a "labor force attachinent" prograin that used services to shift people quickly into work of any kind, decreased the number of AFDC recipients by only $11 \% .^{91}$ The second, slower approach taken by JOBS, a "human capital development" program that

83. Pub. L. No. $100-485,102$ Stat. 2343 (1988) (codified at 42 U.S.C. $\$ \S 601-687$ (1988)).

84. 42 U.S.C. $\S 682$ (1988). Section $602(\mathrm{~g})(1)(A)$ of the FSA also includes a child care "guarantee," or entitlement, which is symbolically significant but has been weakened severely by regulatory, economic and political constraints. See Ann Collins \& Barbara Reisnan, Child Care Under the Family Support Act: Guarantee, Quasi-Entitlement, or Paper Promise?, 11 YALE L. \& POLICY ReV. 203, 214-19 (1993).

85. Robert Moffit, Welfare Reform: An Economist's Perspective, 11 YALE L. \& PoL'Y REV. 126, 140 (1993).

86. Handler, supra note 18 , at 483 , argues that the toughening of work requirements in the AFDC program coincided with changes in the population on welfare rolls and societal attitudes toward non-white single mothers. For an argument that the welfare debate is linked to debates about race, and that as the country has moved to the right, the victim has been the welfare system, see EDSALL, supra note 54.

87. Handler, supra note 18 , at 502 .

88. Id.

89. Joseph A. Califano, Overview: Welfare Reform, 11 YALE L. \& POL'Y REV. 109, 112 (1993). Since JOBS was not funded at a level sufficient to function effectively, it is ludicrous to beheve the current budget-slashing and deficit-minded Congress, see, e.g., infra notes $152-57$ and accoinpanying text, would supply the necessary funds to support welfare-to-work programs today.

90. Gueron, supra note 64, at 117 ("In their 1980s version, welfare-to-work programs ... saved money and imcreased employment somewhat bnt did little to reduce poverty.").

91. Vee Burke, Congressional Research Service issue Brief, Welfare ReFORM 9 (1995). 
encouraged skills-building and postponed employment until recipients were job-ready, did not produce earnings or employment gains for participants. ${ }^{22}$ Part of the problem with JOBS is that child care can cost nearly as much as participants' earnings. Although states are supposed to provide participants with child care, in many states the programs have not inaterialized. ${ }^{93}$ For example, mothers in Dane County, Wisconsin who find full-time employment through JOBS earn an average of $\$ 6.74$ per hour, or $\$ 14,000$ per year. ${ }^{94}$ Day care in that area costs upwards of $\$ 12,000$ per year. ${ }^{95}$ As one journahist reports, "[i]t doesn't take a math genius to figure out the jam that the program participants are $\mathrm{m}$. ${ }^{116}$

WIN and JOBS demonstrate that associating AFDC with work requirements without inaking a concomitant commitment to adequate funding is neither a wise nor a successful strategy to increase family self-sufficiency. Work requirements for AFDC parents, if imposed without the funds necessary to see them through, do hittle to promote the interests of children im AFDC families, rarely alter recipients' "work habits," and frustrate the purposes of both policy pronoting child welfare and pohicy aimed at behavior control.

\section{CHILDREN's "LEGAL RIGHT" TO Welfare}

Arguing that children have a "legal right" to welfare may be an overstatement, because welfare benefits have yet to be declared by the Supreme Court to be a clear legal entitlement or civil right under the Constitution. On the occasions that the Court has considered the matter, however, it has condemned distribution schemes which aim to affect parental behavior at the expense of children. ${ }^{97}$ In addition, although the Court has yet to declare a "fundamental right" to welfare, it has held that, im order for welfare programs to pass constitutional muster, they must supply a rational justification for denying benefits. ${ }^{98}$ These two legal princi-

92. Id.

93. Collins \& Reisman, supra note 84 .

94. Ruth Coniff, Big Bad Welfare, The Progressive, August 1994, at 18, 21.

95. Id. at 21 .

96. Id.

97. See infra part II.A.

98. Id. 
ples warrant consideration when developing welfare policy that denies benefits to children on the basis of moral judgments about their parents.

\section{A. Legal Background}

Commentators argue that the period from 1968 to 1981 witnessed the "legalization of welfare." od resulted in several basic changes in welfare caselaw. Courts established judicial review of administrative decisions denying benefits, ${ }^{100}$ and states were prohibited from changing federal ehgibility requirements ad hoc. ${ }^{101}$ The Supreme Court subjected states' eligibility requirements to fundaniental fairness standards under the Due Process Clause; ${ }^{102}$ the government's power to condition receipt of benefits upon waiver of constitutionally protected liberties was limited; ${ }^{103}$ and equal protection analysis now prohibits states froin setting eligibility standards based on criteria like sex and legitimacy. ${ }^{104}$

The "legalization of welfare" established various welfare rights for children. Courts condemned public benefits schemes that punish dependent children for their parents' conduct. The Supreine Court first recognized in 1968 that a primary purpose of creating the welfare state was to take care of impoverished children unconditionally. According to the Court's decision in King v. Smith, ${ }^{105}$ states are not "free to discourage [childbirth] by the device of absolute disqualification of needy children" from AFDC, as that method "plainly conflicts" with the Social Security Act. ${ }^{106}$ The

99. Law, supra note 79, at 1249. In her article, Professor Law argues that welfare preserves the patriarchy because it assumes that women should be dependent on men, makes aid contingent upon the withdrawal of male economic support, and places a formal employment requirement on welfare mothers, thereby devaluing the work of women who stay home and care for their children.

100. Id at 1267 (citing Hagans v. Lavine, 415 U.S. 528 (1974); Rosado v. Wyman, 397 U.S. 397 (1970); King v. Smith, 392 U.S. 309 (1968)).

101. Id. at 1267-68 (citing cases collected in N. DORSEN, ET AL, Political AND CIVIL RIGHTS IN THE UNITED STATES 1328 (1979)).

102. Goldberg v. Kelly, 397 U.S. 254 (1970).

103. United States Dep't of Agric. v. Moreno, 413 U.S. 528 (1973); Shapiro v. Thompson, 394 U.S. 618 (1969).

104. Califano v. Wescott, 443 U.S. 76 (1979); New Jersey Welfare Rights Org. v. Cahill, 411 U.S. 619 (1973).

105. 392 U.S. 309 (1968).

106. Id. at $326-27$. 
King case involved an Alabama regulation denying AFDC benefits to families where the nother "cohabits" with an able-bodied man. ${ }^{107}$ The Court properly recognized that the "paramount goal of AFDC" is the "protection of . . . children" and therefore forbade administering the program through "Ineasures that punish dependent children" in order to discourage "immorahty or illegitimacy." 108

In addition to the statutory arguments that the Court used in King, constitutional jurisprudence provides precedent for the invahdation of classification schemes based on parental behavior. In Levy v. Louisiana, ${ }^{109}$ the Court held that the denial of the right to recover for wrongful death on the basis of illegitimacy violated the Due Process and Equal Protection clauses of the Constitution. The Court concluded that "it is invidious to discriminate against [illegitimate children] when no action, conduct, or denieanor of theirs is possibly relevant to the harn that was done the inother."110 The rationale of Levy extends easily to welfare rights for children. For example, in his concurrence in King, Justice Douglas made a potent constitutional argument for striking down the Alabama law that disqualified children whose inothers cohabited froin receiving welfare benefits. Justice Douglas found the Alabama law unconstitutional because "the immorahty of the mother has no rational counection with the need of her children under any welfare program." 111

Other Supreme Court decisions have recognized the impermissibility of penalizing children for their parents' behavior, even as these cases have limited the constitutionalization of certain substantive rights that these children have claimed. In Plyler $v$. Doe ${ }^{112}$ for example, the Supreine Court struck down a Texas statute that withheld funds for the education of the children of illegal immigrants. Although children are not a "suspect class" and education is not a "fundamental right," thereby removing the statute froin "coinpelling interest" analysis, the Court found the children's inability to affect their parents' behavior or their own

\footnotetext{
107. Id. at 314.

108. Id. at 325 .

109. 391 U.S. 68 (1968)

110. Id. at 72 .

111. 392 U.S. at 336.

112. 457 U.S. 202 (1982).
} 
illegal alien status legally significant:"13 "Even if the state found it expedient to control the conduct of adults by acting against their children, legislation directing the onus of a parent's misconduct against his children does not comport with fundanental conceptions of justice."114

The Plyler court held that the Texas statute violated the Equal Protection clause based on a rational relationship test, ${ }^{115}$ under which the ineans of allocating the benefits must bear a rational relationship to a permissible government objective. The Texas plan was not rational, according to the Court, because "the children who are plaintiffs in these cases 'can affect neither their parents' conduct, nor their own status."'116

B. Legal Background Applied to "Welfare Reform": Child Exclusion Laws

Current welfare reform efforts, ${ }^{117}$ and particularly their emphasis on child exclusion laws, which deny additional benefits to a family when a child is conceived after the family begins to receive public assistance, run afoul of these Supreme Court holdings. Child exclusion laws violate the purpose of the welfare state; they also fail rationality review. These laws currently exist in sixteen states, all of which obtamed a federal waiver for their AFDC prograins. ${ }^{118}$ The current proposals either eliminate the waiver requirement (as in the Clinton plan), thereby allowing states to freely implement child exclusion laws, ${ }^{119}$ or federalize a child exclusion law (as in the Republican plan), mandating that states participating in AFDC implement them. . $^{20}$

Child exclusion laws "punish dependent children" to deter "immorahty or illegitimacy."121 As has been discussed, the King court struck down such a scheme, finding it violative of the intent of the Social Security Act. Child exclusion laws fail rationahty

113. Id. at 216-24.

114. Id. at 220 .

115. Id. at 223-24.

116. Id. at 220 (quoting Trimble v. Gordon, 430 U.S. 762, 770 (1977)).

117. See infra part III.

118. See Kevin Ryan, Excluding Welfare Babies, AMERICA, Nov. 18, 1995, at 4.

119. See infra part III.A.

120. See infra part III.B.

121. See supra text accompanying notes 105-09. 
review as well because, like the statute in Plyler, they punish children for their parents' conduct, which the children cannot control.

The irrationality of child exclusion laws stems from the fact that they are based on niyth and misconception about welfare families. The inajor misconception embodied by the current proposals is that welfare encourages childbirth and illegitimacy in recipient families. Sociologists and researchers consistently report that additional welfare dollars do not encourage childbirth. The Urban Institute, for example, recently concluded that AFDC generosity does not affect childbearing decisions of young women. ${ }^{122}$ David Ellwood, a Harvard professor serving in President Clinton's Departinent of Health and Hunian Services (HHS), argues that out-of-wedlock birtlis have increased because nrarriage declined, not because pregnancy and childbirth rates have risen. ${ }^{123}$ And in 1994, nearly seventy poverty, labor nrarket, and family structure researchers joined together to issue a statement which asserted that focusing on childbearing decisions creates wayward policy. In their paper, Welfare and Out-of-Wedlock Births: A Research Summary, the researchers agreed on the following findings:

[T] he best social science research suggests that welfare programs are not among the primary reasons for the rising numbers of out-of-wedlock births.... [T] has not played a major role in the rise in out-of-wedlock childbearing. There is, however, strong evidence that poverty harms children. ${ }^{124}$

Finally, the most recent sociological study produced findings that are consistent with the Research Summary. Preliminary reports issued in 1995 by a Rutgers University group commissioned to study New Jersey's child exclusion law found no correlation between welfare recipients' family size and implenientation of the child exclusion law. ${ }^{125}$ These findings denionstrate that the puni-

122. GREgory ACS, ThE URBAN INST., The IMPACT OF AFDC ON YOUNG WOMEN'S CHILDBEARING DECISIONS 17 (1993).

123. EllwOOD, supra note 10, at 72 .

124. Welfare and Out-of-Wedlock Births, A Research Summary (on file with author). For media coverage of the joint statement, see Jean Hopfensperger, Welfare Doesn't Foster Out-of-Wedlock Births, Researchers Declare, STAR-TRIB., June 24, 1994, at 8A.

125. See Michael Kramer, The Myth About Welfare Moms, TiME, July 3, 1995, at 21; Editorial, A Less Patronizing Welfare Debate, WASH. POST, June 23, 1995, at A22; Gary L. Bauer, Family Cap: Incentive for Welfare Moms, ST. LOUIS POST-DiSPATCH, Nov. 17, 1995, at 17D. 
tive measures being proposed today are irrational and therefore unconstitutional.

Common sense also supports the sociologists' findings. The fact that grant levels have declined over time ${ }^{126}$ as illegitimacy has risen ${ }^{127}$ indicates that illegitimacy is not encouraged by welfare. Furthermore, if welfare encourages childbirth in general, then states with the lowest welfare benefits would not consistently have the largest welfare rolls. ${ }^{128}$ Similarly, if the "incentive" of a larger check encourages childbearing, the average welfare family would be larger than the average non-welfare family; in fact, welfare families have the same number of childreu as non-welfare families. ${ }^{129}$

In addition to being based on inaccurate assumptions, child exclusion laws are not rationally designed to achieve their own goals. They are both overinclusive and underinclusive. They are overinclusive in that they penalize children born to women who have not acted "irresponsibly" and can control neither the fact of conception (as in cases of rape, incest, or birth control failure) nor the possibility of conceiving multiple children at one time. In these cases, no plausible argument can be made that "irresponsible" behavior will be discouraged by denying welfare benefits. Child exclusion laws are also underinclusive in that they do not apply to men who become fathers while on public assistance themselves or to men who have children with woinen on assistance. Primarily children and their mothers feel the effects of child exclusion laws.

The lack of a rational relationship between child exclusion laws and their ostensible purposes-discouraging irresponsible

126. See Edin \& Jencks, supra note 9, at 204 ("Welfare benefits have always been low, but their purchasing power has fallen steadily since the mid-1970s . . .."); Ryan, supra note 118, at 4 ("From 1970 to 1990, the average monthly AFDC benefit level, adjusted for inflatiou, declined 36 percent.").

127. See ELLWOOD, supra note 10, at 128; Edin \& Jencks, supra note 9, at 227; Ryan, supra note 118, at 4 ("During this same period, the number of female headed households nearly doubled .... and the extramarital birth rate leaped by two-thirds ....").

128. See Edin \& Jencks, supra note 9, at 227-28.

129. ChILDREN'S DEFENSE FUnD, BASIC FACTS ON WELFARE (on file with author). According to government data, the typical family receiving AFDC has the same number of children as the typical nou-welfare family - about two children. In fact, $74 \%$ of families receiving AFDC in 1991 had two children or fewer. The average number of children in an AFDC family has actually dropped $28 \%$ since 1969. 
childbirth and promoting self-sufficiency-imphes that a different motivation is influencing the current direction of welfare reform. This motivation may be prejudice, based on myths and misconceptions about women, welfare, and motherhood, against the current and growing population receiving AFDC. ${ }^{130} \mathrm{~A}$ more sympathetic, though no less harmful, motivation may be a simple misunderstanding about welfare initiatives of the past and a short institutional memory, as Congress recycles failed ideas and discards longstanding values regarding child welfare. Whatever the motivation, however, laws withholding welfare benefits for no legitimate purpose flatly fail constitutional scrutiny.

One decision that arguably supports the constitutionality of child exclusion laws is Dandridge v. Williams, ${ }^{131} \mathrm{~m}$ which the Supreme Court rejected a challenge to a Maryland "family cap" statute. The Court found that pohicymakers may rationally encourage family planning and may attempt to equalize the mcones of welfare families and wage-earning families, who do not receive an increase in incoine corresponding with the birth of a child, ${ }^{132}$ through the iniposition of a family cap..$^{133}$

It has been argued that child exclusion laws and family caps have the same effect-limiting family incoine-and therefore should receive the same constitutional treatment. The District Court of New Jersey took this approach in C.K. $v$. Shalala, ${ }^{134}$ stating that "New Jersey's cap merely iniposes a ceiling on the benefits accorded an AFDC household while permitting any additional child to share in that 'capped' family income."135 However, the $C . K$. court failed to recognize fundamental differences between these laws. Family caps set a ceiling on family imcome; child exclusion laws deny benefit increases based on the status of the child at conception. The Dandridge decision, therefore, is not applicable to child exclusion laws. There is a fundamental difference between keeping every welfare family of any size below a certain level of

130. See Williams, supra note 43 , at 740-46; Handler, supra note 18 , at 483.

131. 397 U.S. 471 (1970).

132. Id. at $483-84,486$. This analysis ignores deductions per child taken by the family on their incoine taxes.

133. Id. at 486.

134. 883 F. Supp. 991 (D.N.J. 1995). The N.J. Court of Appeals will hear the plaintiffs' appeal of the District Court's summary judgment for the defendant, the State, this year.

135. Id. at 1013. 
income, as in Dandridge, and punishing "after born" children by withholding benefits. The Dandridge Court did not consider a law resulting in a particular child's benefit being taken away. To the contrary, the Court approached Dandridge as a broad challenge to capping benefits for all families on welfare at a particular level, not as a narrow challenge to excluding benefits for additional children born into a family on welfare.

Child exclusion laws also differ from family caps because in a state with a family cap, every child born to AFDC parents receives additional benefits until the cap is reached. Therefore, at least the second child, and frequently the third and fourth children, born imto an AFDC family receives additional benefits. Under a child exclusion law, an additional child is deprived of a benefit increase, even when this child is only the second born. Thus, economies of scale suggest the hardship would not be as great under a family cap as under a child exclusion law.

A final distinction between child exclusion laws and family caps is that under a family cap, the family income level is determined collectively and does not hinge on when a particular child is conceived. In contrast, whether or not a newborn receives additional benefits under a child exclusion law is based not on family income, but solely on whether that child is conceived before or after the family went on welfare. Child exclusion laws therefore openly penalize children based on their status. As discussed above, the Supreme Court has found this type of scheme to be contrary to the intent of welfare legislation and potentially unconstitutional.

\section{The Proposals on the Table: Abandoning OUR COMMITMENT TO CHILDREN}

Welfare reform is at the top of the national agenda. Widespread agreement exists that the welfare system needs changing, and this agreement extends in large part to specifics of the proposed reform plans. Remarkable similarities exist between the Clinton proposal, "The Work and Responsibility Act of 1994,"136 and the Republican bill, "The Personal Responsibility Act of 1995." 137 The identical emphasis on "responsibility" refers to provisions that will penalize adults on welfare who do not conform to

136. H.R. 4605, 103d Cong., 2d Sess. (1994).

137. H.R. 4, 104th Cong., 1st Sess. (1995). 
strict behavioral controls. Although neither bill reahistically addresses poor children's needs, both demonstrate a willingness to punish poor children indirectly for the behavior of their parents. ${ }^{138}$

\section{A. Clinton's "Work and Responsibility Act of 1994"}

President Clinton's reform initiative, "The Work and Responsibility Act of $1994^{\prime 139}$ includes both a work requirement ${ }^{140}$ and a full family sanction, ${ }^{141}$ which provides for the elimination of all family benefits when a parent does not comply with program guidelines. The Act also permits states to inplement child exclusion laws and family caps. There is a time limit in the Clinton proposal that automatically strips away all AFDC benefits after two years of federal assistance, regardless of a family's inability to support itself. ${ }^{142}$

The full family sanction is the most egregious violation of children's rights in the Clinton plan. If a parent refuses to accept private employment without good cause, or fails three tinies to comply with WORKS, the bill's public service provision, ${ }^{143}$ the entire family will be removed from any cash assistance or job program. This plan deviates from the sanctions imposed by current law, under which the government may cut a parent's portion of the grant, but must leave intact that portion of assistance designated for the family's children. ${ }^{144}$ The full family sanction blatantly punishes children based on parental noncomphance.

As discussed in Part II.B of this Note, child exclusion laws and family caps are additional aspects of the Clinton plan which punish poor children in order to influence parental behavior. By eliminating the waiver requirement, which currently prevents states from unilaterally disregarding the eligibility requirements set out in

138. Incidentally, President Clinton recently vetoed a welfare reform conference agreement passed by Congress, based on his conclusion that it "is tough on children" and "is at odds with America's values." Statement by President Clinton (Dec. 21, 1995).

139. H.R. 460S, supra note 136.

140. Id. §§ 201-207.

141. Id. \& 496(f).

142. Id. $\S 104$.

143. Id. § 494.

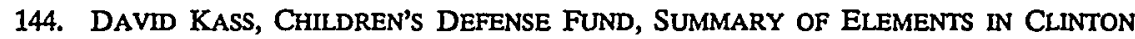
Welfare Reform PROPOSAL (1994) (on file with author). 
the Social Security Act, ${ }^{145}$ the Clinton plan makes such measures easier to implement, granting states the power to wield reproductive control over welfare recipients by denying additional benefits to children born to a family on welfare, or by implementing a per family grant ceiling.

Clinton's plan flatly contradicts the assertions of his own administration that federal waiver requirements are essential to the welfare of children. In testimony before the U.S. House of Representatives, HHS Assistant Secretary Mary Jo Bane stated, "Both Secretary Shalala and I understand the importance of our role [in the waiver process] in ensuring that individuals receiving AFDC, especially children, are protected from harm." ${ }^{146}$ To receive a waiver, she explained, a state's proposed punitive measures must be combined with work programs or other available remedies for people who intend to "[play] by the rules." 147 However, Bane's statements are contradicted by the Clinton plan to jettison the waiver safeguards that HHS deemed essential. ${ }^{148}$

The two-year time limit is another inappropriate puritive policy response in the Clinton plan. Time limits are intended to minimize long-term welfare rehance, but they are based on inaccurate assuniptions about the welfare population. People on welfare comprise a diverse population in need of assistance for various reasons. Contrary to popular behef, most people do not remain on welfare constantly or indefinitely. Instead, many are one-time, short-time users, while others cycle on and off welfare. ${ }^{149}$ Time limits are premised on the inaccurate notion that people need a push into the workforce; in fact, people on welfare already strive to join the workforce, only to find when they do so that they need

145. See supra notes 55-59 and accompanying text.

146. AFDC Waiver Demonstration Programs: Necessary Flexibility or Ad Hoc Decisionmaking?: Before the Subcomm. on Human Resources and Intergovernmental Relations of the House Comm. on Governmental Operations, 103d Cong., 2d Sess. 10, 10 (1994) (statement of Mary Jo Bane, Assistant Secretary for Children and Families, HHS).

147. Id.

148. The President has justified elimination of the waiver requirement as "based on [his] belief, as a former governor, that states should be allowed great flexibility." Barbara Vobejda, Gauging Welfare's Role in Motherhood, WASH. Post, June 2, 1994, at A1, A12. However, state flexibility is a historic aspect of welfare that has compromised many poor children's access to assistance, particularly in the South. See supra notes 43-45 and accompanying text. Because policymakers rejected local control over AFDC in the 1960s, they federalized many of the requirements through amendments to the Social Security Act. See supra notes $45-48$ and accompanying text.

149. See Handler, supra note 27 , at 861 . 
support, including child care ${ }^{150}$ and health insurance, ${ }^{151}$ in order to stay there. Time limits are also based on the assumption that they force people to accept employment that they otherwise would not choose to accept. However, even if this were the case, these jobs do not promote self-sufficiency. They do not bring a family out of poverty or adequately support the children in poor families. The "Help Wanted" signs we might see in the windows of McDonald's represent the type of jobs that do not provide a salary sufficient to pay for the child care and health benefits that working parents require.

\section{B. The Republican "Personal Responsibility Act of 1995"152}

The "Personal Responsibility Act of 1995" is even more punitive than the Clinton plan. It entirely prohibits giving welfare checks to minor mothers, ${ }^{153}$ mandates a federal child exclusion law, ${ }^{154}$ cuts spending for welfare programs, ${ }^{155}$ and enacts "a tough two-years-and-out provision with work requirements to promote individual responsibility." 156 Furthermore, children born out of wedlock are demied assistance permanently. ${ }^{157}$ In terms of indirect pumishment of children for adult behavior, the Clinton plan seems alnost bemign when compared to the stringent imitiatives outlined im the Republican Contract. Although the Republicans' two-year time limit and work requirement mirror the Clinton plan, their exclusion of children born out of wedlock and denial of benefits to teenage mothers go much further in their attempts to mold parental behavior at any cost to children.

By denying any type of aid to children born out of wedlock, the Republican plan places the punishment intended for the "irre-

150. The Children's Defense Fund reports that one out of every four mothers aged 21-29 who did not work in 1986 said the reason was a lack of child care. $34 \%$ of poor mothers said the same thing. CHILDREN's DEFEnse Fund, ChILD CARE \& DevelopMENT DIVISION, KEY FACTS 6 (1994). A 1991 Illinois study found that $20 \%$ of AFDC recipients returned to welfare within a year because of child care problems. NICOLE $O$. Poersche, ChIldren's Defense Fund, Working Parents NeEd Quality ChILd CARE 4 (n.d.) (on file with author).

151. ELLwOOD, supra note 9, at 238.

152. H.R. 4, 104th Cong., 1st Sess. (1995).

153. H.R. 4 \& 105(a).

154. H.R. $4 \S 106(a)$.

155. H.R. $4 \S 301-303$.

156. CONTRACT WITH AMERICA, supra note 1 , at 10 .

157. H.R. $4 \S 105(\mathrm{a})$. 
sponsible" parent squarely upon the child. Withholding assistance to these children in the guise of "defunding" "immoral" premarital sex violates one established societal more: the commitment to assuring that a minimal level of needs is met for all children, regardless of their parents' behavior. ${ }^{158}$ As discussed earlier, this commitment has been reinforced by our legislature and by our courts.

The Republican plan is motivated primarily by an effort to reduce birth rates among the poor ${ }^{159}$ (especially the young and unwed) and will follow its mandate even if it means breaking up poor families. Not surprisingly, the return of the orphanage is part and parcel of the Republican legislation. For example, Representative Richard Talent has sponsored a bill that gives the savings from cutting unmarried teens' AFDC benefits to states to build orphanages. ${ }^{160}$ Such a proposal can only be based upon indifference to our commitment to the welfare of poor children and to our nation's recoguition that child welfare is not promoted by removing children from their families. ${ }^{161}$

Ironically, funding orphanages with savings from AFDC seems to contradict the basic conservative tenets of "family values" and small government because imstitutionalized child care simnltaneously promotes large government and provides for the breakup of the nuclear family. ${ }^{162}$ The inherent inconsistency in Republican proposals possibly derives from the conflicting philosophies of some of the party's thinkers. For example, Charles Murray has influenced policy with his arguments that the welfare state has harmed its intended beneficiaries and imcreased the welfare rolls by creating dependency. ${ }^{163}$ Murray's arguments are convenient

158. See supra parts I \& II

159. The bill summary ("A bill [t]o restore the American family, reduce illegitimacy, control welfare spending and reduce welfare dependence") belies this purpose. A Congressional Research Service report frankly discusses this issue. The report states that althongh the Personal Responsibility Act no longer uses the word "orphanage," "nothing in H.R. 4, as passed by the House, would limit the ability of the states to use [welfare] funds to support foster children in residential or group facilities, which are the modern equivalent of orphanages." KAREN SPAR, CONGRESSIONAL RESEARCH SERVICE, WELFARE REFORM: IMPLICATIONS OF H.R. 4 FOR CHILD WELFARE SERVICES 5 (1995).

160. H.R. $4 \S 108$.

161. See supra part I.A.

162. Conversation with Robert Korstad, Assistant Professor of Public Policy Studies, Duke University (Spring 1995).

163. Charles MURRAY, LosINg Ground (1984). 
fodder for budget-minded politicians eager to cut programs, but have been discredited as based on inaccurate data at best, and, at worst, based on nothing at all. ${ }^{164}$ "Murrayism" also contributes to the trend on the Right to reduce the role of the state, based on the belief that it can do only harm. ${ }^{165}$

Republican social policy is also driven by the conservative authoritarianism, or "New Paternalism," of Lawrence Mead and William Bennett. ${ }^{166}$ "New Paternalism" supports arguments for direct state interference in the lives of the "deviant." This group supposedly includes the welfare population, who allegedly differ froin mainstream society in that they lack discipline and will not adhere to social norms. Coinbining the philosophies of Murray and Mead yields the current Republican welfare reform program: a reduction of inonetary assistance and a simultaneous increase in governmental institutional care.

\section{Conclusion: "Codifying a Policy of National Child ABANDONMENT"}

The Clinton and Republican proposals trample this nation's moral and legal commitment to children. As a prominent child advocate recently said, these bills, with their family caps, full family sanctions, and time limits, "destroy the 60-year-old guaranteed safety net [created by the Social Security Act] for children, women and poor families ...."167 The focus on parental beliavior eliminates a commitment to children and "codif[ies] a policy of national child abandonment."168 For example, a mother with one child who has a second under a family cap or child exclusion law ex-

164. See, e.g., THEODORE R. MARMOR, ET AL., AMERICA'S MISUNDERSTOOD WELFARE STATE: PERSISTENT MYTHS, ENDURING REALITIES 114 (1990)(“[W]e can at least feel confident that our efforts to relieve poverty lave not been causing it to grow."); Jason DeParle, Daring Research or 'Social Science Pornography'?: Charles Murray, N.Y. TIMES Magazine, Oct. 9, 1994, at 48.

165. For examples of this trend and belief, see Lee May, Reagan, Deficit Shapes Debate on Social Issues Series: '88 Candidates and the Issues: Social Programs, L.A. TIMES, Nov. 16, 1987, at A1.

166. See LAWRENCE N. MEAD, BEYOND ENTITEMENT: THE SOCLAL OBLIGATIONS OF CITIZENSHIP (1986). For a discussion of Bennett's views, see Jason DeParle, In Welfare Debate, It's Now Not 'How?' but 'Why?', N.Y. TIMES, May 8, 1994, \& 4, at 1 (quoting Bennett's view that orphanages would be an inprovement over the status quo).

167. Marion Wright Edelman, Say No to This Welfare 'Reform', WASH. Post, Nov. 3, 1995, at A23.

168. Id. 
periences approximately an $8 \%$ reduction in welfare benefits. Her income would decline froin $57.5 \%$ of the federal poverty line to $53.2 \%{ }^{169}$ If a family cap provision is implemented fully, the Department of Health and Human Services estimates that 2.2 million children would be denied AFDC benefits. ${ }^{170}$

This shift froin policies that ensure minimal child welfare to punitive measures intended to control parents' behavior is demonstrated by the difference in stated goals between AFDC and current reform legislation. While AFDC's goals include "encourag[ing] care of needy children in their own homes," "strengthen[ing] family life," and "promot[ing] family self-support," the current bills aim to "end dependence of needy parents upon government benefits," and "discourage out-of-wedlock birtlis." "171

Proponents of the current reform plans disregard our tradition of unconditional assistance to children (albeit at a minimal level) as they promote their ideals of "responsibility." These policymakers are willing to sacrifice child welfare in order to attentpt to control parental behavior. The Clinton reform bill and the Republican "Contract" both purportedly take the moral high ground, claiming that they inust reniove parental incentives to act "irresponsibly." But both bills cliart a path which violates this country's historical, moral and judicial commitment to aiding helpless children. Full family sanctions, family caps, and child exclusion laws make for good political rhetoric when Americans face a treinendous budget deficit and middle-class voters liave been forced to tighten their belts. But these policies violate inpoverished children's rights and run counter to the historic evolution of childcentered welfare policy and welfare initiatives. These policies are thus wholly unjustifiable.

Sociologists, academics, econonnists, and policymakers have suggested alternatives to the rlietoric of responsibility that dominates the wayward plans of President Clinton and the Republicans. They advocate economic policy to improve job opportunities, ${ }^{172}$ a

169. Carmen D. Solomon, Congressional Research Service, Welfare ReFORM: THE FAMILY CAP 2 (1995).

170. Id. at 4 .

171. Vee Burke, Congressional Research Service, Cash Welfare for Families With ChIldReN: Comparison of House-Passed H.R. 4 and Senate LEADERSHIP ALTERNATIVES 2 (1995).

172. See generally Edin \& Jencks, supra note 9 (arguing that the welfare problem is not dependence, but lack of jobs); Lynn, supra note 10 (arguing that effective welfare 
meanimgful child care guarantee ${ }^{173}$ health care reform, ${ }^{174}$ federally guaranteed child support, ${ }^{175}$ and caretaker allowances, ${ }^{176}$ to name just a handful. These alternatives approach welfare reform from the perspective of larger societal issues, rather than simply imposing hardships on mdividual children to influence their parents.

Discarding this country's long-standing commitment to child welfare would further erode the shaky foundation beneath an entire generation of America's poor children. To do so on the basis of the rhetoric of responsibility would be fundamentally irresponsible, immoral, and unconstitutional.

reform needs to take account of labor market problems, rather than push welfare mothers into an already poor labor market).

173. See Collins \& Reisman, supra note 84 .

174. See Handler, supra note 27 , at $866,868-69$.

175. See Minow, supra note 11 , at 841 .

176. See Gwendolyn Mink, Welfare Reform in Historical Perspective, 26 CoNN. L. REV. 879, 899 (1994). 